\title{
Transformasi Pendidikan Kristen Dalam Konteks Kebangsaan Indonesia
}

\author{
Yornan Masinambow \\ Institut Agama Kristen Negeri Manado \\ Email: yornanmasinambow@gmail.com
}

\begin{abstract}
Education is an important part of every life in this advancing human civilization. In Indonesia with its diversity, education is important for the progress of the nation. However, education in Indonesia is still based on the western style of education. It also penetrated the religious education in this case Christian education that historically Christianity developed during the colonial era. Christian education that is present has a western perspective and is exclusive to Indonesia's pluralistic society. Therefore, Christian education needs to transform to fit the context of Indonesia's pluralistic nationality. Through the explanation in the discussion, it can be said that the transformation of Christian Education in the context of the Indonesian nationality is inclusive, dialogical, and respects, respects various kinds of local cultural backgrounds, religions in Indonesia. Through the transformation, the identity of Christian education became an Indonesian original that respected pluralism and was no longer supported by the exclusively western doctrinal style. The transformation of Christian education in the Indonesian context also emphasizes the values of Pancasila as a shared identity and harmony as a basis for learning, and theologically presenting love for others.
\end{abstract}

Keywords: Christian Education, Transformation, Nationality, Indonesia, Plurality.

\begin{abstract}
Abstrak
Pendidikan merupakan bagian penting dalam setiap kehidupan dalam hal ini memajukan suatu peradaban manusia. Begitupun di Indonesia dengan kemajemukannya, pendidikan menjadi hal yang penting bagi kemajuan bangsa. Namun, pendidikan di Indonesia masih berpatokan pada corak pendidikan barat. Hal tersebut juga merambah pada pendidikan agama dalam hal ini pendidikan Kristen yang secara historis kekristenan berkembang pada waktu zaman penjajahan. pendidikan Kristen yang hadir berwawasan barat serta bercorak esklusif dalam masyarakat Indonesia yang plural. Oleh karena itu, pendidikan Kristen perlu untuk mengalami transformasi agar sesuai dengan konteks kebangsaan Indonesia yang majemuk. Artikel ini menggunakan penelitian studi kepustakaan, melalui pengkajian serta perumusan konsep pendidikan Kristen yang ditransformasi dalam konteks kebangsaan Indonesia. Melalui paparan dalam pembahasan dapat dikatakan bahwa transformasi pendidikan Kristen konteks kebangsaan Indonesia bersifat inklusif, dialogis, serta menghargai, menghormati berbagai macam latar belakang budaya lokal, agama di Indonesia. Melalui transformasi tersebut identitas pendidikan Kristen menjadi orisinil Indonesia yang menghargai kemajemukan serta tidak lagi terkukung oleh corak doktrinal esklusif barat. Transformasi pendidikan Kristen dalam konteks Indonesia juga menekankan nilai-nilai Pancasila sebagai identitas bersama dan
\end{abstract}


juga kerukunan sebagai dasar pembelajaran, serta secara teologis menghadirkan cinta kasih bagi sesama.

Kata-kata Kunci: Pendidikan Kristen, Transformasi, Kebangsaan, Indonesia, Majemuk

\section{PENDAHULUAN}

Kemajemukan identik dengan Indonesia, dikarenakan Indonesia terdiri dari masyarakat atau suku bangsa yang ratusan dengan banyaknya agama, kepercayaan yang disatukan melalui unsurunsur atau perangkat yang secara nasional teratur, tertata sebagai bangsa yakni Negara Kesatuan Republik Indonesia (Retnowati, 2009). Stefanus menambahkan bahwa Indonesia terdiri atas berbagai macam unsur-unsur dengan pluralitas yang ada baik dari segi agama, suku, latar belakang etnis, budaya berada di Indonesia. Keseluruhan dari Nusantara Indonesia terbentang sekitar tujuh belas ribu tujuh ratus enam puluh pulau dan kurang lebih tiga ratus suku bangsa dengan banyaknya bahasa, sejarah serta ragam budaya (Stefanus, 2009). Berdasarkan realitas kemajemukan tersebut, maka salah satu aspek penting yang harus disoroti serta mampu memberikan pemahaman secara mendalam terkait pluralitas di Indonesia yakni pendidikan. Hal ini dikarenakan pendidikan merupakan suatu tindakan atau aktivitas yang memiliki kesadaran akan adanya tujuan serta sifatnya yang berkesinambungan serta dinamis, berkembang dari masa ke masa sesuai konteks zaman. (Tulung, 2014). Selain itu, maju dan berkembangnya suatu pendidikan menjadi salah satu faktor keberhasilan suatu bangsa, termasuk bangsa Indonesia. Namun secara global, indikasi yang selama ini dilihat bahwa kemajuan yang harus dialami berdasarkan kemajuan dari perspektif atau pola dunia barat, seperti di Amerika dan Eropa, dimana mereka inilah yang selalu menjadi patokan termasuk pendidikan. Indonesia sendiri sebagai bangsa atau negara majemuk yang terus menerus berkembang mencari cara, posisi, ataupun upaya tentang bagaimana membentuk bangsa Indonesia yang dapat menjadi negara maju khususnya pada aspek pendidikan termasuk di dalamnya pendidikan Kristen (Munirah, 2015). Perlu juga diperhatikan mengenai kesadaran masyarakat Indonesia yang lampau tentang bagaimana pentingnya nasionalitas bangsa untuk mampu mempertahankan identitas dari bangsa-bangsa yang melakukan penjajahan. Pada waktu mengalami penjajahan, masyarakat Indonesia sadar bahwa penindasan membuat mereka kehilangan hak merdeka. Oleh karena itu, 
muncullah sebuah harapan serta tekad yang besar bahwa di masa depan bangsa Indonesia dapat berkembang serta mampu untuk bersaing dengan negara-negara maju lainnya. Oleh karena itu, pendidikan merupakan salah satu jalan yang mampu untuk mewujudkannya (Aritonang, 2019).

Kesadaran tentang pentingnya pendidikan juga tertuang dalam peraturan pemerintah RI No.55 tahun 2007 tentang pendidikan agama dan keagamaan. Di dalamnya dijelaskan pada pasal 1 serta pasal 2 bahwa pendidikan agama memberikan suatu sikap, kepribadian serta pengetahuan berdasarkan pengamalan atau penghayatan ajaran agama yang kemudian dapat membentuk manusia Indonesia yang taat kepada Tuhan Yang Maha Esa serta mampu untuk menjaga kedamaian juga kerukunan hubungan inter dan antarumat beragama (Perpres, 2007).

Oleh karena itu, pendidikan agama yang diajarkan melalui proses pembelajaran di sekolah maupun dalam lembaga agama secara khusus gereja hendaknya mampu untuk memberikan suatu pembinaan iman, spiritualitas bagi umatnya untuk menuju pada kesejahteraan dan kedamaian. Namun di sisi lain perlu diperhatikan secara kritis bahwa pendidikan agama juga berciri khas atau bercorak eksklusif dan bisa jadi tidak sesuai dengan konteks realitas kebangsaan Indonesia yang majemuk (Tulung, 2014).
Begitupun dengan pendidikan Kristen saat ini yang pada umumnya merupakan representasi pendidikan Kristen yang bercorak Barat khususnya di Amerika Serikat, namun keterhubungannya terutama dengan Eropa pada umumnya tidak bisa dilepaskan. Di dalamnya termuat aspek-aspek doktrinal yang kalau ditelaah lebih dalam lagi ada yang cenderung bercorak eksklusif fundamentalis. Misalnya, pemahaman ajaran mengenai Alkitab melalui interpretasi secara harafiah. Alkitab memang merupakan pedoman yang benar bagi kehidupan manusia serta di dalamnya terdapat Firman Tuhan yang benar serta tidak perlu diragukan lagi. Tetapi jikalau menganggap kehidupan sosial dalam aspek kemanusiaan haruslah terjadi sesuai dengan interpretasi Alkitab secara harafiah seyogyanya perlu ditinjau lagi. Alkitab juga merupakan kumpulan kitab-kitab yang diterima sebagai kanon merupakan bagian dari karya manusia sekalipun diakui bahwa di dalam karya manusia itu Tuhan berkenan menyatakan kehendak-Nya. Akan tetapi, Tuhan yang hidup melalui Firman-Nya tidak berhenti setelah Alkitab dikanonkan. Tuhan tidak bisa dibatasi oleh tindakan putusan-putusan manusia karena manusia sifatnya terbatas (Titaley, 2020). Rantung menjelaskan bahwa pandangan eksklusif fundamentalis atau eksklusivisme dalam kehidupan beragama pada dasarnya 
menjadi akar masalah dalam keberagaman hidup masyarakat yang plural. Eksklusivisme mempunyai pemahaman bahwa ide, paradigma, dogma atau pola pikir merekalah yang paling benar, dapat menjadi acuan, bahkan superior dibanding dengan pandangan-pandangan yang lain. (Djoys Anneke Rantung, 2017). Dalam lingkup kekristenan misalnya semboyan bahwa "di luar gereja tidak ada keselamatan" serta "di luar Kristus tidak ada keselamatan" menjadi hal yang perlu untuk ditinjau lagi. Meskipun hal tersebut sifatnya dogmatis, tetapi dampak tersebut juga sampai ke dalam aspek sosio-politis dan juga kultur di mana masyarakat tersebut hidup. Secara historis, kekristenan yang datang di Indonesia termasuk daerahdaerah lokal dalam hal mengabarkan Injil tidak mewujudkan suatu paradigma Asia yang kontekstual melainkan penginjilan yang masuk bersamaan dengan penjajahan dan sadar atau tidak membuat Injil tersebut terbungkus dengan suasana kultur Barat yang kemudian menjustifikasi kultur dan simbol lokal yang ada (Pinontoan, 2020). Hal ini terlihat, misalnya dari para Pekabar Injil atau Misionaris Eropa yang datang pada abad ketujuh belas hingga abad keduapuluh secara bersamaan dengan kolonialisme. Eksploitasi terhadap nusantara termasuk alam demi keuntungan dalam ekonomi atau perdagangan bangsa barat juga menjadi sasaran dalam konteks untuk menaklukan wilayah nusantara. Jadi, sangat terasa nuansa politis yang ada. Oleh karena itu, perlu ada suatu transformasi terhadap pekabaran Injil yang bercorak eksklusif dari barat dari konteks keIndonesiaan. (Djoys Anake Rantung, 2017). Eksklusivitas tersebut dirasakan pada waktu penjajahan bangsa-bangsa Eropa khususnya Belanda dimana budaya lokal Indonesia tiap-tiap daerah sangat dibatasi bahkan sampai dilarang. Hal tersebut dilakukan karena adanya pemikiran bahwa budaya-budaya lokal tersebut lebih rendah serta tidak mendapatkan tempat dari budaya Eropa yang dominan serta mereka juga menganggap bahwa hal tersebut bertentangan dengan iman Kristen (Lauterboom, 2019). Pada masa penjajahan di zaman VOC, pendidikan Kristen terjalin atau terikat erat dengan pekabaran Injil serta beberapa alasan berdirinya gerejagereja agar dapat mengembangkan iman kepercayaan khususnya mengenai kekristenan serta untuk mempersatukan orang-orang VOC dengan masyarakat setempat, maka salah satu instrumen yang dilihat baik yakni melalui adanya sekolah. Tetapi perlu diperhatikan bahwa terdapat unsur kepentingan politis, ekonomis mengenai berbagai macam kebijakan tentang pengembangan gereja serta pendidikan atau sekolah (Sianipar, 2017). Selanjutnya, Romo Y.B. Mangunwijaya 
sebagaimana dikutip oleh Ramopolii juga menyatakan bahwa Indonesia yang merupakan bangsa bekas jajahan menjadi faktor sulitnya memerdekakan diri dari sistem kolonial, termasuk dalam dunia pendidikan. Bahkan secara tidak sadar, jiwa kolonial/feodal pada saat ini pun dipupuk sehingga semakin kolonial jugalah dunia Pendidikan (Ramopolii, 2020). Pendidikan keagamaan termasuk di dalamnya pendidikan Kristen perlu untuk mengalami transformasi berdasarkan ciri khas bangsa Indonesia. Telah menjadi realitas bersama bahwa kehidupan masyarakat sekarang ini telah terbawa pada paham fundamentalisme doktrinal agama yang semakin menguat dan pada perkembangannya telah menciptakan manusia-manusia fanatik serta menutup diri pada realitas kemajemukan yang ada di sekitarnya (Wattimena, 2016). Hal ini bisa terjadi oleh karena pola pembelajaran yang tidak bersifat dialogis, para pengajar bersifat superior-inferior sehingga terciptanya suatu dikotomi dalam proses pembelajaran serta kurangnya critical thinking skills yang membuat naradidik menerima secara pasif informasi yang didapat termasuk didalamnya pemikiran yang bercorak eksklusif serta radikal.

Pandangan-pandangan tersebut dapat membuat masyarakat tidak lagi menaruh perhatian serta menekankan betapa pentingnya pendidikan yang berorientasi pada aspek historis sosial khususnya mengenai kebangsaan. Jika dibiarkan maka akan berakibat pada lunturnya atau pudarnya semangat nasionalis kebangsaan tersebut. Bahkan bisa menjurus pada disintegrasi bangsa. Masyarakat pun perlu diingatkan kembali pentingnya untuk mengutamakan pendidikan kebangsaan. (Hermawan, 2015). Barangkali masalah yang bisa timbul dari paham eksklusif fundamentalis seperti itu dalam konteks Indonesia yang majemuk adalah bahwa kaum rohaniwan, agamawan serta para pendidik dapat menemui kesulitan apabila berjumpa dalam suatu dialog itu dengan mereka yang tidak sepaham dalam hal merefleksikan kepercayaan mereka, atau menghayati iman mereka secara universal berdasarkan keuniversalan dalam kehidupan manusia. Oleh karena itu, saling menghargai, menghormati keberadaan masing-masing dalam hidup bersama dalam suatu transformasi pendidikan dalam konteks keberagaman Indonesia perlu untuk dilakukan tanpa harus meninggalkan identitas masing-masing.

Berdasarkan penjelasan di atas maka tulisan ini hendak mengkaji serta merumuskan suatu konsep pendidikan Kristen dalam konteks Indonesia yang telah mengalami transformasi sebagai suatu identitas baru yakni pendidikan Kristen yang inklusif, dialogis, interaktif, serta menghargai juga menghormati, 
keberagaman atau kemajemukan yang ada di Indonesia. Melalui pendidikan Kristen konteks kebangsaan inilah Indonesia dapat berkembang dan maju serta mampu untuk menyejajarkan diri dengan konsep.

\section{METODE PENELITIAN}

Metode penelitian dalam tulisan ini menggunakan metode kualitatif dengan pendekatan studi kepustakaan yakni aktivitas penelitian keilmiahan yang melakukan penelahaan secara kritis sistematis terkait bahan-bahan kepustakaan yang berguna secara langsung dengan subjek yang diteliti (Salim, 2012). Dengan menggunakan pendekatan studi ini, penulis membahas serta melakukan analisa secara konseptual pandangan-pandangan yang diambil dari berbagai jurnal ataupun bukubuku yang relevan dengan topik yang ada (Suryabrata, 2019). Studi kepustakaan ini secara khusus mengarah pada membahas teori serta konsep yang sudah ada yaitu pendidikan Kristen konteks Indonesia kemudian digunakan penulis untuk melakukan analisis serta melakukan interpretasi data (Afrizal, 2017). Terkait penelitian dalam tulisan ini, penulis yang adalah instrumen penelitian hendak mengkaji secara khusus mengenai pendidikan Kristen yang transformatif dari perspektif keindonesiaan. pendidikan-pendidikan lain secara global serta mewartakan kabar baik bagi sesama tanpa kukungan dogma barat yang eksklusif fundamentalis serta memandang sesama manusia adalah setara.

\section{Pendidikan Kristen}

Mengutip pemikiran Chomsky, ada tiga hal penting tentang pendidikan seperti yang dijelaskan oleh Wattimena. Pertama, pendidikan sebenarnya harus mampu menghasilkan manusia-manusia yang dapat berelasi dalam keadaan, kedudukan apapun yang setara, tidak ada subordinasi di dalamnya. Kedua, pendidikan dapat memberikan suatu pembelajaran hidup untuk dapat membangun relasi yang mau mengasihi tidak menguasai dalam hal ini penguasaan terhadap sesama ciptaan, manusia dan juga alam. Ketiga, Pendidikan secara dinamis merupakan proses untuk mengadakan warga negara, masyarakat yang baik, bijak serta setara (Wattimena, 2012). Oleh karena itu, Pendidikan memiliki suatu daya, kuasa untuk mengubah, mentransformasi sesuatu menjadi lebih baik bahkan lebih buruk, karena dari pendidikanlah segala sesuatu dimulai. Pendidikan pun menjadi suatu sarana agar manusia dapat menjadi manusia yang utuh dan manusia yang utuh berarti memiliki kemanusiaan (Ramopolii, 2020). Perlu diperhatikan juga bahwa pendidikan mempunyai tujuan penting 
yakni mencerdaskan kehidupan bangsa, agar suatu negara tidak tertinggal jauh dari negara-negara yang lainnya. Agen-agen perubahan yang mencintai pendidikan dapat mengaplikasikan kecintaannya tersebut dalam menekankan pentingnya belajar, bersekolah terhadap semua warga Indonesia. Agen-agen perubahan tersebut mempunyai kesadaran untuk mengasihi serta perduli terhadap bangsalah dapat mengubah pendidikan Indonesia agar menjadi lebih baik (Megawanti, 2012). Dengan demikian, pendidikan selalu berusaha membawa orang-orang yang ingin belajar agar mereka dapat keluar dari kegelapan pikiran mereka menuju terang dari pengetahuan dan kebijaksanaan.

Dalam aturan Undang-Undang sistem Pendidikan Nasional tahun 2003, dikatakan bahwa pendidikan agama, merupakan pendidikan yang dapat memberikan suatu pengetahuan serta dapat membentuk sikap, pribadi juga keterampilan para pembelajar dalam mereka memikirkan, menghayati ajaran nilai-nilai agamanya yang dijalankan melalui berbagai mata pelajaran semua jalur serta berbagai macam jenjang dan jenis Pendidikan (UU Sisdiknas No.20 tahun 2003). Kemudian, penjelasan dalam peraturan Menteri Agama Republik Indonesia Nomor 16 tahun 2010 mengenai Pengelolaan Pendidikan Agama juga menjelaskan dalam salah satu poin bahwa tujuan standar pendidikan agama ialah menjadikan agama atau kepercayaan sebagai fondasi dasar terkait kelakukan, budi pekerti dalam kehidupan secara personal, keluarga, masyarakat, bangsa serta negara (Sianipar, 2017). Selain itu, pendidikan merupakan suatu hal yang paling memungkinkan untuk digunakan, dihayati dalam menggapai cita-cita melalui transformasi dalam masyarakat disebabkan fungsinya sebagai instrumen perubahan berkaitan dengan nilai dan sikap mental manusia. Dari aspek teologis secara konseptual mengenai pendidikan Kristen, dikatakan bahwa tujuan pendidikan Kristen ialah untuk memberikan pertolongan kepada mereka yang mau memahami serta menaati karya Tuhan terhadap ciptaan-Nya dalam setiap kehidupan mereka. Ada suatu komitmen serius bagi penyelenggaraan pendidikan Kristen untuk memikirkan dengan benar dan mendalam tentang bagaimana membangun kehidupan peserta didik dalam konteks kekristenan (Santoso, 2005). Selain itu menurut Seymour, pendidikan Kristen merupakan dialog atau percakapan kehidupan yang mau untuk mengerahkan segala tenaga, pikiran, badan berdasarkan pengharapan akan iman kepercayaan serta kultur yang adil untuk terus dijalankan dalam suatu budaya yang ada (Seymour, 2016). Pendidikan Kristen juga adalah instrumen yang indah sekaligus kuat dalam hal menghadirkan suatu 
persekutuan bagi sesama manusia, siapapun itu, baik yang sama beragama maupun yang berbeda agama. Lebih lanjut, pendidikan Kristen juga mampu untuk menyatakan bahwa manusia sebagai mahkluk sosial dan juga personal merupakan sebuah representasi dari Tuhan Yang Mahakuasa (Djoys Anake Rantung, 2017).

\section{Pendidikan Kebangsaan Indonesia}

Mengutip pemikiran Titaley yang menyatakan bahwa kebangsaan merupakan pemahaman modern dalam aspek sejarah kehidupan manusia terutama setelah terbentuknya negara-negara bangsa baru dari cara hidup yang sebelumnya yakni masyarakat tradisional. Ia menambahkan bahwa pengaruh dari modernitas termasuk di dalamnya pendidikan dapat membawa perkembangan kehidupan baik secara ekonomi, sosial semakin meluas dalam berbagai bidang sehingga masyarakat tidak bisa lagi hidup berdasarkan dasar tradisional di daerah masing-masing saja. Ketika persoalan hidup masyarakat modern tersebut berhadapan dengan dimensi pengaturan hidup bersama secara politis, muncullah gagasan kebangsaan dalam kehidupan masyarakat modern itu (Titaley, 2020). Pendidikan kebangsaan dapat dikatakan sebagai suatu sistem pembelajaran yang selalu bertolak dari pemikiran yang bersifat nasional. Dengan begitu, negara akan terus menghadirkan manusia-manusia Indonesia yang berguna, mencintai sesamanya, baik secara individu, keluarga, maupun kolektif dalam hal ini masyarakat. Dari sisi historis, perjuangan kemerdekaan yang diprakarsai oleh pergerakan dari Boedi Oetomo dan juga Ki Hajar Dewantoro lewat Perguruan Taman Siswa, sudah memberikan tanda bahwa sebenarnya pendidikan kebangsaan sudah berdiri dan terus digaungkan. Semangat nasionalismelah yang menjadi tujuan untuk menghadirkan pendidikan kebangsaan, agar rakyat Indonesia terbebas dari pengaruh pikiran-pikiran atau mental penjajah yang ada pada waktu itu. (Hermawan, 2015). Oleh karena itu, sikap mengenai kebangsaan perlu dihadirkan, ditanamkan dalam diri setiap orang, generasi demi generasi melalui Pendidikan. Memberikan edukasi tentang Indonesia merupakan hal yang perlu untuk dipertimbangkan dalam dunia Pendidikan.

Pendidikan kebangsaan Indonesia juga dapat meningkatkan kesadaran terkait karakter peserta didik di tengah-tengah kemerosotan moral serta sikap yang berlawanan dengan nilai-nilai agama khususnya Kristen dan juga Pancasila sebagai dasar negara. Oleh karena itu, pendidikan termasuk pendidikan Kristen yang mengalami transformasi melalui pendidikan kebangsaan ini dapat memberikan penekanan pada penanaman 
nilai-nilai karakter nasional kebangsaaan yang dilaksanakan dengan pendekatan melalui pembelajaran, pembudayaan, serta keteladanan. Para pengajar pendidikan Kristen, baik di gereja maupun sekolah punya peran yang sangat penting untuk mengarahkan peserta didik dalam pengembangan karakter kristiani berwawasan kebangsaaan Indonesia (Sidjabat, 2019).

Sejak awal, negara Indonesia lahir dari keberagaman, dimana penduduk yang berada di kepulauan yang masing-masing berbeda-beda wilayahnya pada saat yang sama juga berbeda bahasa-bahasanya serta tradisi, kultur bahkan kepercayaannya pun sangat berbeda satu dengan yang lain. Ini merupakan suatu fakta atau realitas klasik. Akan tetapi, pembentukan negara-bangsa pada awal abad kedua puluh menjadi tonggak penting untuk mempersatukan berbagai macam komunitas yang beragam baik etnis, status sosial, agama, bahkan pulau-pulau yang ada. Di bawah suatu identitas nasional Pancasila inilah maka kepelbagaian tersebut mampu disatukan dalam konteks Indonesia (Bagir, 2011). Pembangunan karakter Indonesia melalui konsep filosofis Pancasila dapat memijarkan pandangan hidup yang meyakini bahwa kehendak bersama secara sosial dapat diwujudkan secara tertib dengan bersatu serta harmoni dalam perbedaan yang mampu diraih manakala mampu mengembangkan hubungan welas asih dengan Yang Mahasuci kemudian memancarkan semangat ketuhanan yang berkebudayaan, lapang, dan toleran, mengasihi sesama manusia, memancarkan juga semangat kemanusiaan yang adil dan beradab dalam hubungan manusia dengan ruang hidup (Tanah Air) dan pergaulan hidupnya dalam kebangsaan serta memancarkan persatuan dalam keragaman bangsa. Penekanan terhadap Ketuhanan, serta persatuan, kemudian spiritualitas yang memberikan penekanan pada kesadaran terhadap kemanusiaan, serta berintegritas, beretos kerja yang positif dan kreatif serta sanggup menjalin persatuan (gotong-royong) dengan semangat musyarawah dan keadilan, dan pelayanan (Latif, 2020). Pandangan tersebutlah yang harus dijadikan suatu pengetahuan dasar serta pembelajaran dasar di sekolah, keluarga bahkan institusi keagamaan yang kemudian harus terus dihayati secara dinamis yang bersifat reflektif teologis dalam konteks pendidikan Kristen yang bercita rasa Indonesia yang majemuk.

\section{Transformasi Pendidikan Kristen dalam}

\section{Kemajemukan Indonesia}

Transformasi pendidikan secara majemuk merupakan bagian eksploratif secara sosial dimana hal tersebut menjadi tujuan dan proses pendidikan dapat diwujudkan. Pendidikan Kristen yang 
transformatif menjadikan Kerajaan Allah sebagai dasar dalam melaksanakan praksis untuk mewujudkan keadilan sosial yang terwujud dalam suatu relasi kehidupan bersama secara setara, tidak merasa unggul satu dengan yang lain, bebas juga harmonis. Shaw menyatakan bahwa transformasi pendidikan harus berdasarkan suatu refleksi teologis berdasarkan realita yang terjadi dalam kehidupan sosial serta pemaknaan filosofis melalui pendidikan yang nyata, bersumber dari kehidupan social-scientific dan tidak bersifat abstrak. Ia juga menambahkan bahwa transformasi pembelajaran secara holistik perlu untuk ditekankan agar para pendidik secara teologis mampu menghadirkan para naradidik sebagai pemimpin Kristiani di masa depan yang bertanggung jawab (Shaw, 2014).

Dalam konteks Indonesia, transformasi pendidikan kristen memiliki tujuan yaitu, mempromosikan ciri dari kewarganegaraan yang berilmu, serta menghayati identitas kebersamaan secara kolektif dalam satu kesatuan. Hal ini didasari karena pendidikan Kristen berasal dari, oleh, dan untuk warga gereja dan pada saat yang sama merupakan warga negara, yang bersifat publik, semua buat semua dan tidak eksklusif. Kemudian transformasi pendidikan dalam aspek sosial menekankan perubahan. Maksudnya adalah adanya upaya reorientasi iman dari setiap pribadi kepada suatu komunitas (Seymour, 2016).

Hattu menyatakan bahwa transformasi pendidikan di Indonesia dalam tataran kehidupan sosial masyarakat dapat diselenggarakan pada orientasi kegiatan pengembangan kemampuan setiap orang melalui pemikiran reflektif secara kritis, serta mendorong partisipan untuk terlibat dalam kegiatan sosial kemanusiaan (Hattu, 2020). Dalam ranah pendidikan Kristen diupayakan untuk mengembangkan, mengenali serta terampil dalam menciptakan, mengubah suatu perdamaian lebih baik lagi dan menyatakan hidup yang adil di tengah-tengah dunia, tentu saja dengan tuntunan Tuhan melalui anugerah-Nya secara vertikal dan respons melalui solidaritas antar persektuan secara horizontal (Monding, 2020). Keriapy juga menjelaskan bahwa transformasi pendidikan Kristen dalam konteks kemajemukan di Indonesia seyogyanya harus dapat menghadirkan sikap toleransi serta menghargai sesama. Untuk dapat mewujudkannya, maka sekolah dan juga gereja yang harus berinisiatif memulainya. Pendidik, pengajar atau guru tidak saja mentransfer ilmu secara kognitif melainkan menghadirkan diri mereka melalui nilai-nilai karakter kristiani inklusif yang mampu menjadi patron atau teladan bagi karakter nara didik dari setiap pembelajar (Keriapy, 2020). Melalui 
sekolah dan gereja, para guru, rohaniwan pendidikan Kristen dapat memberikan pembelajaran iman berbasis kesadaran solidaritas, kasih kepada sesama komunitas, khususnya terkait dengan pentingnya nilai-nilai kebangsaan dalam konteks masyarakat majemuk berdasarkan keprihatinan atas realitas sosial yang terjadi. Ini berarti, penghormatan serta penghargaan atas keberadaan kehidupan sesama manusia ciptaan Tuhan menjadi suatu isu yang sangat penting.

\section{Memperkuat dan menghayati Pendidikan}

\section{Kristen secara Indonesia}

Kemajemukan Indonesia merupakan kenyataan yang ada dalam kebangsaan dimana kita hidup sebagai masyarakat. Berdasarkan hal tersebut ada dua hal penting yang dapat menjadi dasar kuat serta identitas secara bersama-sama yakni Pancasila dan Kerukunan di Indonesia yang kemudian direfleksikan secara teologis oleh pendidikan Kristen.

Pendidikan Kristen dengan Nilai-nilai Pancasila

Dinamika perubahan yang terjadi saat ini sangat cepat yang disertai oleh berbagai macam pemikiran dari kultur asing baik secara filosofis, teologis, serta perkembangan ilmu pengetahuan dan teknologi selalu terus mendatangi, membanjiri berbagai macam aspek kehidupan masyarakat Indonesia. Oleh karena itu penekanan terhadap pendidikan Kristen yang menekankan nilai-nilai Pancasila sangat dibutuhkan dalam hal membentuk karakteristik pemikiran manusia Indonesia yang orisinil, bermoral, integritas serta professional. Hal yang paling penting juga terkait adanya pendidikan Pancasila adalah identitas bangsa Indonesia tetap dijaga, tidak mudah untuk tercabut dari akar sosial, budaya masyarakat serta melalui Pancasilalah, seluruh identitas pendidikan di Indonesia termasuk pendidikan Kristen menjadi pembeda dengan bangsa-bangsa yang lain. (Paristiyani Nurwardani, 2016).

Dengan begitu, pendidikan Kristen secara Indonesia dapat memberikan suatu edukasi teologis dalam hal penghayatan pembelajaran mengenai kemajemukan serta pentingnya Pancasila sebagai dasar negara Republik Indonesia. Inilah realitas dasarnya serta tidak boleh diingkari dalam kehidupan kebangsaan Indonesia. Indonesia adalah majemuk sekaligus Pancasila yang sekaligus merupakan pandangan hidup (weltanschauung), sebagai dasar negara. Kalau hal tersebut dikaji lebih mendalam, maka gagasan mendasar kehidupan Negara, bangsa Indonesia itu adalah perlakuan terhadap semua manusia Indonesia secara setara. Setiap orang Indonesia, misalnya mereka 
yang beragama Kristen dalam suatu kebersamaan dalam nilai-nilai Pancasila membuat mereka seyogyanya memperlakukan yang lain adil, setara karena sebangsa apapun kepercayaannya. Kesetaraan, keadilan yang dimaksudkan bukan saja secara kesukuan, yaitu Jawa dengan Sumatera, Sulawesi, Papua dan lain sebagainya, akan tetapi juga setara dalam hal agama, yaitu Islam, Kristen, Hindu, Buddha, serta Konghucu, juga setara dalam sistem ekonomi yang adil bagi semua orang. Sekali lagi, secara khusus hal-hal tersebut tidak hanya berlaku bagi orang Kristen Indonesia, akan tetapi bagi semua manusia yang berbangsa Indonesia (Titaley, 2020). Para pengajar atau guru agama Kristen, kaum rohaniwan dengan sikap terbuka serta adil juga memiliki peranan penting dalam hal memberikan edukasi tentang betapa pentingnya nilainilai kebangsaan di dalam praksis masyarakat yaitu pentingnya toleransi antarumat beragama, menghargai perbedaan, memberikan pemahaman yang mendalam mengenai ciri khas keindonesiaan seperti Bhineka Tunggal Ika, Pancasila, UUD 1945 dan NKRI agar supaya perselisihan atau konflik antarkelompok masyarakat, antarkelompok agama, antargolongan, dan antaretnis dapat dihindari (Wahyuni, 2018). Perbedaan golongan, etnis, identitas dalam konteks kemajemukan Indonesia seringkali menimbulkan kesenjangan antar kelompok atau pihak yang satu dengan yang lain. Ada sifat merasa lebih unggul dari kelompok satu ke kelompok yang lainnya. Oleh karena itu, prinsip penting dari pendidikan kebangsaan dengan dasar Pancasila adalah untuk menghadirkan perdamaian dengan menghindari setiap kecenderungan berprasangka buruk terhadap mereka yang lain dan berusaha untuk mengenali juga menghargai perbedaan (Darmawan, 2019). Hal tersebut dapat dinyatakan melalui kesadaran bahwa manusia adalah mahkluk sosial yang dapat mengembangkan pergaulan hidup kebangsaan yang ditandai oleh segala kemajemukannya dengan menanamkan mentalitas gotong royong, "bhinneka tunggal ika" atau persatuan dalam keragaman (Latif, 2020). Pendidikan yang diajarkan kepada manusia dengan semangat gotong royong, persatuan manusia dalam konteks ini warga negara Indonesia bisa dikembangkan dengan menghargai adanya perbedaan, sedang dalam perbedaan, bisa merawat persatuan.

\section{Pendidikan Kristen dan Kerukunan}

Untuk dapat mewujudkan kerukunan dalam kehidupan bermasyarakat Indonesia, perlu untuk terus mewartakan sikap kebersamaan atau disebut dengan istilah lain persatuan dan kesatuan. Mengutip pemikiran Yewangoe yang menyatakan bahwa dalam konteks 
Indonesia, meningkatkan kerukunan adalah dengan membangun persatuan dan kesatuan yang mana terkandung suatu "perjanjian luhur" dari bangsa Indonesia. Di dalamnya tersirat satu janji yang terus diwartakan, bukan hanya kepada sesama bangsa Indonesia, tetapi yang terutama adalah di hadapan Tuhan, dimana keadaan berbangsa serta bernegara dalam konteks Indonesia hanya dapat dijamin jika persatuan dan kesatuan terus dipelihara serta dapat dibina. Persatuan lebih mengacu pada aksi yang sifatnya dinamis, sedangkan kesatuan adalah hasil dan/atau akibat dari aksi-aksi atau juga upaya-upaya membangun persatuan (Yewangoe, 2018). Terkait hal tersebut, pendidikan Kristen keindonesiaan terkait kerukunan juga harus mengajarkan kepada setiap pembelajar kemampuan untuk dapat memberikan suatu sikap dialogis, bercorak inklusif, dimana setiap orang dalam suatu komunitas, golongan dapat saling mengisi atau melengkapi, berkomunikasi satu dengan yang lain dengan prinsip persatuan dan kesatuan. Oleh karena itu, pada praksisnya dalam pendidikan Kristen, kita tidak hanya berfokus pada suatu tataran doktrinal saja tentang keunikan Iman Kristen sendiri tetapi pada saat yang sama menekankan hal-hal etis-moril dalam beragama, yang tentu saja memiliki orientasi mengasihi bangsa Indonesia yang lebih besar daripada orientasi keagamaan yang fanatik, tertutup, serta fundamentalis. Pendidik Kristen perlu memperhatikan serta memberikan suatu penekanan pada pola pembelajaran bahwa untuk mencapai kerukunan, sikap untuk menghargai perbedaan tidak perlu disikapi secara diskriminatif. Secara teologis edukatif, representasi kasih Kristus perlu ditunjukkan dimana hal tersebut harus menjadi bagian dari perilaku setiap hidup orang percaya khususnya masyarakat Indonesia. Perilaku itu tentunnya merupakan representasi ekspresif iman kepada Kristus untuk mengasihi sesama manusia (Darmawan, 2019). Selain itu, untuk memperkuat pendidikan kebangsaan sebagai karakter khususnya terhadap pembelajar di Indonesia yakni mengimplementasikan nilai-nilai budi pekerti yang juga terdapat dalam nilai-nilai keagamaan termasuk Kekristenan. Pendidikan Kristen secara Indonesia yang memperhatikan kerukunan setiap umat juga berlandaskan pada nilai-nilai teologis alkitabiah, misalnya mengajarkan, serta menghidupi bahwa Tuhan Yang Mahakuasa mengasihi, umat manusia ciptaan-Nya. Disini orang Kristen harus menyadari bahwa mereka berada di bumi ciptaan Tuhan dan tetap milik-Nya serta bernaung bersama dengan saudara-saudara sesama ciptaan Tuhan dan milik Tuhan yang sama (Sirait, 2016). Dasar biblis, dalam Kejadian 1:1 yang menyatakan 
bahwa "Pada mulanya Allah menciptakan langit dan bumi”, yang berarti keberadaan di bumi dan secara khusus termasuk masyarakat Indonesia dengan berbagai macam latar belakang perbedaan, suku, etnis, ras bahkan agama merupakan ciptaan Tuhan yang sama (Djoys Anake Rantung, 2017). Stott juga menyatakan bahwa Tuhan adalah Tuhan dari alam semesta, Dialah pencipta dari seluruh ciptaan, dan bukan hanya Tuhan dari umat pilihan-Nya (Stott, 2005). Kustini juga menyatakan bahwa dalam konteks Kekristenan, mengasihi Tuhan, dan mengasihi sesama merupakan hal yang harus menjadi pijakan bersama. Ia menambahkan bahwa kemanusiaan menjadi dasar dari hukum kasih tersebut. Oleh karena jikalau hanya mengasihi sesama Kristen bukanlah bagian dari Kekristenan. Disinilah letak keuniversalan kasih Tuhan bagi sesama melintasi wilayah, suku, agama, menyentuh kemanusiaan melintasi sekat-sekat bangsa. Pada saat yang sama pun hal tersebut menjadi dasar penerimaan kehidupan berbangsa, sebab kemanusiaan terdapat pada wilayah kebangsaan (Kustini, 2016). Dengan begitu, Pendidikan Kristen dalam konteks kebangsaan yakni Indonesia mampu untuk mengajarkan tentang kerukunan serta menumbuhkan kesadaran bahwa relasi dengan sesama merupakan bagian integral dari suatu proses kehidupan di Indonesia yang majemuk. Orang Kristen pun dapat mengakui kehadiran orang lain yang berbeda-beda. Oleh karena itu, kita hidup sebagai manusia-manusia Indonesia. Orang Kristen yang telah dan terus memaknai secara teologis mengenai Pancasila dalam kehidupannya secara praksis harus memperlakukan sesamanya sebagai saudara sebangsa walaupun mereka beragama atau mempunyai latar belakang yang lain. Hal tersebut tidak hanya berlaku bagi seorang Indonesia yang beragama Kristen, akan tetapi bagi semua bangsa Indonesia. Secara teologis juga, Indonesia yang sudah merdeka adalah berkat dan rahmat yang datang dari Tuhan Yang Mahakuasa, Tuhan Yang Hidup. Dasar tersebutlah yang seharusnya menjadi kesadaran yang dihidupi serta menjadi pijakan Pendidikan Kristen dalam konteks Indonesia yang harus terus dihayati dalam setiap proses pembelajaran.

\section{KESIMPULAN}

Dari berbagai macam penjabaran penulis, dapat dikatakan bahwa transformasi pendidikan Kristen dalam konteks kebangsaan Indonesia merupakan hal yang penting bagi warga gereja, warga masyarakat atau secara menyeluruh yakni manusia-manusia Indonesia. Dengan melakukan transformasi pendidikan Kristen, maka percakapan kehidupan, dengan berbagai macam latar belakang yang berbeda dapat menjadi satu dan bisa 
menghadirkan masa depan dengan wajah kesetaraan, kerukunan, keadilan, dan saling berpengharapan satu dengan yang lain. Pendidikan Kristen dalam konteks kebangsaan Indonesia bersifat insklusif, nasionalis, dialogis, menghargai sesama yang berbeda baik secara budaya, ras, etnis maupun juga antar kepercayaan agama. Proses pembelajaran secara dinamis terus diupayakan bagi para pendidik untuk pengembangan karakter nara didik secara keindonesiaan dengan mencintai serta menghidupi nilai-nilai yang ada dalam Pancasila. Pendidikan Kristen yang ditransformasi melalui kebangsaan Indonesia setidaknya mampu menekan paham esklusif, fundamentalis, doktrinal judgment yang superior terhadap yang lain, serta arus globalisasi dari dunia barat. Pendidikan Kristen kebangsaan Indonesia juga dapat menjadi ciri khas bagi dunia pendidikan untuk diwartakan sampai ke ujung bumi. Hal-hal tersebutlah yang dapat menjadi suatu kekuatan baru bagi pengembangan pendidikan di Indonesia.

\section{DAFTAR PUSTAKA}

Afrizal. (2017). Metode Penelitian Kualitatif. Rajawali Pers.

Aritonang, A. (2019). Kekristenan Dan Nasionalisme Di Indonesia. Jurnal Amanat Agung, 15(1), 111-141. https://doi.org/10.47754/jaa.v15i1.34
4

Bagir, Z. A. (2011). Pluralisme Kewargaan Arah Baru Politik Keragaman di Indonesia. Kawistara, 1(2011).

Darmawan, I. P. A. (2019). Pendidikan Perdamaian Dengan 12 Nilai Dasar Perdamaian. BIA': Jurnal Teologi Dan Pendidikan Kristen Kontekstual, 2(1), $55-71$. https://doi.org/10.34307/b.v2i1.82

Hattu, J. V. D. (2020). Keterkaitan Pendidikan Kristiani di Sekolah dan Gereja. Indonesian Journal of Theology, 7(1), 25-45. https://doi.org/10.46567/ijt.v7i1.4

Hermawan, P. A. (2015). Pentingnya Pendidikan Kebangsaan.

Kompasiana.Com.

https://www.kompasiana.com/herum awanpa/550dea7fa33311b12dba7da9/ pentingnya-pendidikan-kebangsaan.

Keriapy, F. (2020). Pendidikan Kristiani Transformatif Berbasis Multikultural dalam Konteks Indonesia. REGULA FIDEI: Jurnal Pendidikan Agama Kristen, $\quad$ 5(2), 82-93. http://christianeducation.id/ejournal/index.php/regulafidei/article/ view/55

Kustini. (2016). Kekristenan Dan Nasionalisme Di Kota Bogor. Jurnal Harmoni, 15(2), 96-108. 
Latif, Y. (2020). Pendidikan yang Berkebudayaan: Histori, Konsepsi, dan Aktualisasi Pendidikan Transformatif. Gramedia Pustaka Utama.

Lauterboom, M. (2019). Dekolonisasi Pendidikan Agama Kristen di Indonesia. Indonesian Journal of Theology, $\quad 7(1), \quad 88-110$. http://www.elsevier.com/locate/scp

Megawanti, P. (2012). Meretas Permasalahan Pendidikan Di Indonesia. Formatif, 2(3), 227-234. https://doi.org/10.30998/formatif.v2i 3.105

Monding, Y. D. (2020). Tinjauan Teologis tentang Pendidikan Seks dari Perspektif Pendidikan Kristiani Transformatif. Pengarah: Jurnal Teologi Kristen, 2(2), 173-182. https://doi.org/10.36270/pengarah.v2i 2.39

Munirah, M. (2015). Sistem Pendidikan di Indonesia: Antara Keinginan Dan Realita. Jurnal Pendidikan Islam Dasar, 2(2), 233-245.

Paristiyani Nurwardani, D. . (2016). Pendidikan Pancasila Untuk Perguruan Tinggi. Direktorat Jenderal Pembelajaran dan Kemahasiswaan Kementerian Riset, Teknologi dan Pendidikan Tinggi.
Perpres. (2007). Pendidikan Agama dan Pendidikan Keagamaan. In Peraturan Pemerintah RI: Vol. Nomor 55.

Pinontoan, N. A. H. \& D. H. R. (2020). Ritual Mahtambulelen dan Kekristenan di Minahasa. In I. Y. M. L. \& T. Kholiludin (Ed.), Agama \& Budaya Nusantara Pasca Kristenisasi (p. 217). eLsA Press.

Ramopolii, M. C. (2020). Pemerdekaan: Pendidikan dan Teologi YB. Mangunwijaya Menghadapi Revolusi Industri 4.0. Kanisius.

Rantung, Djoys Anake. (2017). Pendidikan Agama Kristen Dan Politik Dalam Kehidupan Masyarakat Majemuk di Indonesia. In Shanan Jurnal Pendidikan Agama Kristen (Vol. 1, Issue

http://ejournal.uki.ac.id/index.php/sh an/article/view/1492

Rantung, Djoys Anneke. (2017). Pendidikan Agama Kristen dalam Kehidupan Masyarakat Majemuk. Lintang Rasi Aksara Books.

Retnowati. (2009). Masyarakat Indonesia yang Majemuk dan Perawatannya: Suatu Pendekatan Multikultur. Jurnal Waskita, 4(1), 4.

Salim, S. (2012). Metodologi Penelitian Kualitatif: Konsep dan Aplikasi dalam Ilmu Sosial, Keagamaan dan 
Pendidikan. Media Citapustaka.

Santoso, M. P. (2005). Karakteristik Pendidikan Kristen. Seminari Alkitab Asia Tenggara. http://repository.seabs.ac.id/handle/1 $23456789 / 121$

Seymour, J. L. (2016). Memetakan Pendidikan Kristiani: PendekatanPendekatan Pembelajaran Jemaat. BPK Gunung Mulia.

Shaw, P. (2014). Transforming Theological Education: A Practical Handbook for Integrative Learning. Langham Global Library.

Sianipar, D. (2017). Pendidikan Agama Kristen Yang Membebaskan: Suatu Kajian Historis Pak di Indonesia. In Shanan Jurnal Pendidikan Agama Kristen (Vol. 1, Issue 1). http://ejournal.uki.ac.id/index.php/sh an/article/view/1481

Sidjabat, B. S. (2019). Penguatan Guru Pak Untuk Pendidikan Karakter: Melihat Kontribusi Seri Selamat. Evangelikal: Jurnal Teologi Injili Dan Pembinaan Warga Jemaat, 3(1), 30-48.

Sirait, S. (2016). Teologi Kenegaraan: Negara dalam Rancangan Tuhan. BPK Gunung Mulia.

Stefanus, D. (2009). Pendidikan Agama
Kristen Kemajemukan. Bina Media Indonesia.

Stott, J. (2005). Isu-isu Global Menantang Kepemimpinan Kristiani: Penilaian Atas Masalah Sosial dan Moral Kontemporer. Yayasan Komunikasi Bina Kasih OMF.

Suryabrata, S. (2019). Metodologi Penelitian. Rajawali Pers.

Titaley, J. A. (2020). Berada dari Ada Walau Tak Ada. eLsA Press.

Tulung, J. M. (2014). Pendidikan Agama Kristen Dalam Masyarakat Majemuk. Eksekutif, 1(3), 1-12.

Wahyuni, marina nova. (2018). Pendidikan dan Kebangsaan. M.Mediaindonesia.Com. https://mediaindonesia.com/opini/179 629/pendidikan-dan-kebangsaan.

Wattimena, R. A. A. (2012). Pendidikan manusia-manusia demokratis filsafat pendidikan Noam Chomsky relevansi serta keterbatasannya pada konteks Indonesia. Jurnal Filsafat Arete.

Wattimena, R. A. A. (2016). Tentang Manusia. In Yogyakarta: Maharsa.

Yewangoe, A. A. (2018). Agama dan Kerukunan. BPK Gunung Mulia. 